\title{
Rhizosphere Dehydrogenase Activity, Soil Organic Carbon and Post-Harvest Nutrient Status of Soil as Influenced by Hybrids, Planting Density and Fertility Levels of Maize in Irrigated Eco-System of Northern Karnataka
}

\author{
Mohan Kumar R* \\ Scientist (Agronomy), All India Co-ordinated Research Project on Castor, India
}

*Corresponding author: Mohan Kumar R, Scientist (Agronomy), All India Co-ordinated Research Project on Castor, India

\section{ARTICLE INFO}

Received: 幽 November 13, 2019

Published: 櫘 November 19, 2019

Citation: Mohan Kumar R. Rhizosphere Dehydrogenase Activity, Soil Organic Carbon and Post-Harvest Nutrient Status of Soil as Influenced by Hybrids, Planting Density and Fertility Levels of Maize in Irrigated Eco-System of Northern Karnataka. Biomed J Sci \& Tech Res 23(1)-2019. BJSTR. MS.ID.003845.

Keywords: Dehydrogenase; Organic Carbon; NPK; Maize Hybrids; Planting Density; Fertility Level

\begin{abstract}
The soil sample of effective root zone of the maize crop with respect to soil dehydrogenase activity, organic carbon and available post-harvest nutrient status indicated variation across treatments. Dehydrogenase activity and organic carbon status of soil not differed significantly due hybrids and planting densities of maize. However, dehydrogenase activity and organic carbon status of soil were decreased with increase in fertility levels at 45 and 90 days after sowing. Significantly higher activity of dehydrogenase activity and soil organic carbon status was observed with maize fertilized with $\mathrm{N}_{(150)} \mathrm{P}_{2} \mathrm{O}_{5(65)} \mathrm{K}_{2} \mathrm{O}_{(65)}$ kg per hectare (24.86 and 30.57, respectively at 45 and 90 days after sowing) than rest of the fertility levels imposed. Among the maize hybrids, plots cultivated with hybrid Arjun recorded significantly higher available nitrogen (268.3 $\mathrm{kg} / \mathrm{ha})$, phosphorous (67.2 kg/ha) and potassium (462.1 kg/ha) status of the soil than NK-6240 and Super 900-M. Between the planting density maize cultivated at lower planting density (83, 333 plant/ha) resulted in higher available nitrogen $(239.9 \mathrm{~kg} / \mathrm{ha})$, phosphorous $(72.9 \mathrm{~kg} / \mathrm{ha})$ and potassium $(461.4 \mathrm{~kg} / \mathrm{ha})$ than higher planting density $(1,11,111$ plants/ha). Available nutrient status of the soil increased gradually with successive elevation in fertility levels. Significantly higher available nitrogen (259.0 $\mathrm{kg} / \mathrm{ha}$ ), phosphorous (76.9 kg/ha) and potassium (493.1 kg/ha) status of the soil was observed with application of $\mathrm{F}_{5}-\mathrm{N}_{(300)} \mathrm{P}_{2} \mathrm{O}_{5(130)} \mathrm{K}_{2} \mathrm{O}(130)$ per hectare to maize.
\end{abstract}

\section{Introduction}

Maize was the untouched crop of Indian green revolution; today it occupied a pride place among the cereals in India, because it is considered as promising option for diversifying agriculture in both rainfed and irrigated eco-systems. Its adoptability in various cropping systems as component crop made it to stand in third position after rice and wheat. In India, maize related research programs have now given focus on single cross hybrids. Since 1990, large number of single cross hybrids of normal and quality protein maize have been released and they made the spectacular difference in maize production. Further, it was well documented by earlier worker [1] that single cross hybrids were flexible to planting density and fertility levels. Increased response of recently developed maize hybrids to high density planting and elevated fertility levels encourages the grower to habituate mono-culturing of maize even in the nontraditional areas of maize, as a resultant of continuous cultivation of high biomass producing maize there is an apprehension of deteriorating soil resource base due to lack of diversity and nutrient mining.

Hence, to know the probable changes of soil chemical and biological properties present study was undertaken because, oil dehydrogenases are the major representatives of the Oxidoreductase enzymes class [2]. Among all enzymes in the soil 
environment, dehydrogenases are one of the most important and are used as an indicator of overall soil microbial activity [3] because they occur intracellular in all living microbial cells [4]. Moreover they are tightly linked with microbial oxidoreduction processes [5]. Dehydrogenases play a significant role in the biological oxidation of soil organic matter by transferring hydrogen from organic substrates to inorganic acceptors [6]. Further, available nutrient status is another index which decides the crop growth and productivity. Hence, a field experiment and concurrent laboratory study was undertaken to assess the cause and effects of maize hybrids, elevated plant population and fertility levels on soil health and fertility was studies for two cropping seasons (Kharif 2013 and 2014).

\section{Material and Method}

\section{Experimental Site Characteristics and Experimental Design}

A field experiment was conducted during kharif 2013 and 2014 at Agriculture Research Station Farm, Mudhol to study the effects of single cross hybrids, plant population and level of fertilization on growth and yield attributes, yield, nutrient use efficiency and economics of maize production. The experiment was laid out in split-split plot design and was replicated thrice. Three hybrids ( $\mathrm{H}_{1}$-NK-6240, $\mathrm{H}_{2}$-Super 900-M and $\mathrm{H}_{3}$-Arjun), two populations $\left(P_{1}-1,11,111\right.$ and $P_{2}-83,333$ plants ha-1) and five fertility levels $\left(\mathrm{F}_{1}-\mathrm{N}_{(150)} \mathrm{P}_{2} \mathrm{O}_{5(65)} \mathrm{K}_{2} \mathrm{O}_{(65)}\right.$ (RDF), $\mathrm{N}_{(187)} \mathrm{P}_{2} \mathrm{O}_{5(81)} \mathrm{K}_{2} \mathrm{O}_{(81)}$ (125\% of RDF), $\mathrm{N}_{(225)} \mathrm{P}_{2} \mathrm{O}_{5(97)} \mathrm{K}_{2} \mathrm{O}_{\text {(97) }}\left(150 \%\right.$ of RDF), $\mathrm{N}_{(262)} \mathrm{P}_{2} \mathrm{O}_{5(114)} \mathrm{K}_{2} \mathrm{O}_{(114)}(175 \%$ of RDF), $\mathrm{N}_{(300)} \mathrm{P}_{2} \mathrm{O}_{5(130)} \mathrm{K}_{2} \mathrm{O}_{(130)}(200 \%$ of RDF) were assigned to main plot, sub-plot and sub-sub plots, respectively. Data on initial chemical properties of the soil presented in the Table 1 . The soil of the experimental site was deep black soil. The soil was alkaline in reaction and low in organic carbon. The soil nutrient status of soil was low in available nitrogen (237 $\left.\mathrm{kg} \mathrm{ha}^{-1}\right)$ and phosphorous (23 kg $\mathrm{ha}^{-1}$ ) and high in available potassium (427 $\mathrm{kg} \mathrm{ha}^{-1}$ ) (Table 1).

Well decomposed farmyard manure at the rate of 10 tones and $25 \mathrm{~kg} \mathrm{ZnSO}_{4}$ and $\mathrm{FeSO}_{4}$ per hectare was applied uniformly over all the treatments and seeds were treated with phosphorus solubilizing bacteria and Azospirullam each at the rate of $750 \mathrm{~g}$ per hectare. As per the treatments seed rows at $45 \mathrm{~cm}$ and $60 \mathrm{~cm}$ were opened to accommodate 1,11, 111 and 83, 333 plants per hectare in sub plots. Inter row spacing of $20 \mathrm{~cm}$ was maintained for both the populations. Basal dose of nitrogen (15\% of RDN), phosphorous (100\% $\mathrm{RDP}_{2} \mathrm{O}_{5}$ ), potassium $\left(\mathrm{RDK}_{2} \mathrm{O}\right)$ and micronutrients were applied at the time of sowing and reaming quantity nitrogen was applied in four splits. And all crop management practices were followed as per the recommendation made by University of Agricultural Sciences, Dharwad [7].

\section{Soil Analysis}

Soil samples were drown from the effective root zone of the maize crop $(0-45 \mathrm{~cm})$, freshly collected soil samples was subjected to quantification of dehydrogenase activity and was estimated by using 2, 3, 5 triphenyal tetrazolium chloride using $1 \mathrm{~g}$ of field moist soil ( $<2 \mathrm{~mm}$ particle size) and expressed as $\mu \mathrm{g}$ of triphenyl formazan (TPF) formed per gram of oven dry soil per 24 hours [8]. Further, for the post-harvest soil analysis for organic carbon and available nitrogen, phosphorous and potassium soil samples were collected from Ap horizons at 0-45 cm soil depth in all the treatments after harvest of maize in each year. The samples were air dried at room temperatures and passed through a $2 \mathrm{~mm}$ sieve and homogenated. Soil organic carbon content was estimated by the standard dichromate oxidation method. Mineralizable nitrogen was estimated by distillation with alkaline $0.32 \%$ potassium permanganate, available phosphorus was estimated calorimetrically by blue color method after extraction with sodium bicarbonate solution and available potassium was extracted with neutral $1 \mathrm{~N} \mathrm{NH}_{4} \mathrm{OAc}$.

\section{Statistical Analysis}

For the proper presentation of data all soil factors was analyzed statistically by standard analysis of variance (ANOVA) and differences were separated by standard error means (S.Em) using M-STAT-C software. To find out error mean sum of squares (EMSSq), Microsoft- Excel software (Microsoft Corporation, USA) was used and significant differences were determined at LSD $(p=0.05)$.

\section{Result and Discussion}

\section{Dehydrogenase Activity}

Dehydrogenase activity is the manifestation of total microbial load, which indicate the mineralization capacity of plant nutrient in soil. Hence, assessment of its activity at peak nutrient demanding stages of the maize crop like beginning silking (45 DAS) and grain filling stage (90 DAS) is necessary. Dehydrogenase activity at 45 and 90 days after sowing did not influenced by hybrids and planting density (Table 2). It confirms genotypes and altered planting geometry do not having significant influence on soil dehydrogenase activity. However, fertility levels imposed to the maize crop significantly influenced the dehydrogenase activity of the soil on pooled basis during both the stages of observation. Generally, dehydrogenase activity of the soil decreased as the fertility levels increased. Significantly higher dehydrogenase activity of soil was noticed with application of $\mathrm{N}(150) \mathrm{P}_{2} \mathrm{O}_{5}$ (65) $\mathrm{K}_{2} \mathrm{O}$ (65) $\mathrm{kg}$ per hectare at 45 and 90 DAS $\left(24.86\right.$ and $30.57 \mathrm{mg} \mathrm{TPF} \mathrm{g}^{-1}$ soil day ${ }^{-1}$, respectively) over other fertility levels (Table 2). Fertility levels $\mathrm{F}_{2}$ (22.90 and $26.09 \mathrm{mg} \mathrm{TPF}^{-1}$ soil day ${ }^{-1}$, respectively), $\mathrm{F}_{3}$ (21.02 and $23.62 \mathrm{mg} \mathrm{TPF}^{-1}$ soil day ${ }^{-1}$, respectively) and $\mathrm{F}_{4}$ (17.77 and $20.97 \mathrm{mg} \mathrm{TPF} \mathrm{g}^{-1}$ soil day ${ }^{-1}$, respectively) were next in the order on pooled basis. Significantly lower activities of dehydrogenase at 45 and 90 DAS was noticed with application of $\mathrm{N}(300) \mathrm{P}_{2} \mathrm{O}_{5}$ (130) $\mathrm{K}_{2} \mathrm{O}$ (130) kg per hectare $\left(\mathrm{F}_{5}\right)$ (15.30 and $19.39 \mathrm{mg} \mathrm{TPF}^{-1}$ soil day ${ }^{1}$, respectively) these findings are in the close agreement with the findings of Nath et al. [9]. 


\section{Soil Organic Carbon}

Irrespective of the treatments imposed, the soil organic carbon content decreased over the years of experimentation when compared to initial soil status (Table $1 \& 2$ ). It could be due to no residue retention in the field after harvest of maize under intensive cropping practices. Particularly among the maize hybrids and between the plant population levels organic carbon content of the soil not differed significantly (Table 1) over the years of study. However, among the fertility levels slight decrease in organic carbon status of the soil with elevated fertility levels was observed but was not statistically significant. Initially organic carbon status of the experimental site was 0.42 per cent and was in the range of 0.395 to 0.412 per cent during 2013 and later during 2014 it was in the range of 0.388 to 0.413 per cent on pooled mean basis (Table 2 ).

Table 1: Initial chemical properties of experimental site (before starting of experiment).

\begin{tabular}{|c|c|c|c|c|c|}
\hline Sl. No. & Particulars & Values & Unit & Methodology & Remarks \\
\hline 1 & $\mathrm{pH}$ & 7.91 & - & Potentiometric method & Alkaline \\
\hline 2 & Electrical conductivity & 0.37 & $\mathrm{dS} \mathrm{m}^{-1}$ & Conductometric method & Non saline \\
\hline 3 & Organic carbon & 0.42 & Percentage & Wet oxidation & Low \\
\hline 4 & Available nitrogen & 237 & \multirow{3}{*}{$\mathrm{kg} \mathrm{ha}^{-1}$} & Alkaline permanganate method & Low \\
\hline 5 & Available phosphorous & 23 & & 0.5 M Sodium bicarbonate method & Medium \\
\hline 6 & Available potassium & 427 & & Flame photometry & High \\
\hline
\end{tabular}

Table 2: Rhizosphere dehydrogenase activity ( $\mu \mathrm{g} \mathrm{TPF}^{-1}$ soil day ${ }^{-1}$ ), soil organic carbon as influenced by hybrids, plant population and fertility levels of maize (Pooled data of two years).

\begin{tabular}{|c|c|c|c|c|}
\hline \multirow{2}{*}{ Treatment } & \multicolumn{2}{|c|}{ Dehydrogenase Activity (mg TPF $\mathrm{g}^{-1}$ soil day ${ }^{-1}$ ) } & \multicolumn{2}{|c|}{ Soil Organic Carbon (\%) } \\
\hline & 45 DAS & 90 DAS & 2014 & 2015 \\
\hline \multicolumn{5}{|c|}{ Maize Hybrids (H) } \\
\hline $\mathrm{H}_{1}-\mathrm{NK}-6240$ & $20.79 a$ & $24.25 a$ & $0.400 \mathrm{a}$ & 0.390a \\
\hline $\mathrm{H}_{2}$-Super $900-\mathrm{M}$ & $20.41 \mathrm{a}$ & $23.88 \mathrm{a}$ & $0.404 \mathrm{a}$ & $0.403 \mathrm{a}$ \\
\hline $\mathrm{H}_{3}$-Arjun & $19.91 \mathrm{a}$ & $24.26 \mathrm{a}$ & $0.407 a$ & $0.413 a$ \\
\hline S. Em. \pm & 0.48 & 1.38 & 0.016 & 0.005 \\
\hline \multicolumn{5}{|c|}{ Plant Population ha' ${ }^{-1}(\mathrm{P})$} \\
\hline$P_{1}-1,11,111$ & $20.56 a$ & $23.83 a$ & $0.408 \mathrm{a}$ & $0.398 \mathrm{a}$ \\
\hline$P_{2}-83,333$ & $20.18 \mathrm{a}$ & $24.43 a$ & $0.400 \mathrm{a}$ & $0.406 \mathrm{a}$ \\
\hline S. Em. \pm & 0.38 & 0.71 & 0.011 & 0.006 \\
\hline \multicolumn{5}{|c|}{ Fertilization Levels kg ha-1 $(F)$} \\
\hline $\mathrm{F}_{1}-\mathrm{N}(150) \mathrm{P}_{2} \mathrm{O}_{5}(65) \mathrm{K}_{2} \mathrm{O}(65)$ & $24.86 \mathrm{a}$ & $30.57 a$ & $0.409 a$ & $0.401 \mathrm{a}$ \\
\hline $\mathrm{F}_{2}-\mathrm{N}(187) \mathrm{P}_{2} \mathrm{O}_{5}(81) \mathrm{K}_{2} \mathrm{O}(81)$ & $22.90 \mathrm{~b}$ & $26.09 \mathrm{~b}$ & $0.412 \mathrm{a}$ & $0.413 \mathrm{a}$ \\
\hline $\mathrm{F}_{3}-\mathrm{N}(225) \mathrm{P}_{2} \mathrm{O}_{5}(97) \mathrm{K}_{2} \mathrm{O}(97)$ & $21.02 c$ & $23.62 \mathrm{c}$ & $0.403 a$ & $0.408 \mathrm{a}$ \\
\hline $\mathrm{F}_{4}-\mathrm{N}(262) \mathrm{P}_{2} \mathrm{O}_{5}(114) \mathrm{K}_{2} \mathrm{O}(114)$ & $17.77 \mathrm{~d}$ & $20.97 d$ & $0.395 \mathrm{a}$ & $0.402 \mathrm{a}$ \\
\hline $\mathrm{F}_{5}-\mathrm{N}(300) \mathrm{P}_{2} \mathrm{O}_{5}(130) \mathrm{K}_{2} \mathrm{O}(130)$ & $15.30 \mathrm{e}$ & $19.39 \mathrm{~d}$ & $0.402 \mathrm{a}$ & $0.388 \mathrm{a}$ \\
\hline S. Em. \pm & 0.42 & 0.6 & 0.014 & 0.005 \\
\hline
\end{tabular}

Note: Means followed by same letter (S) with in a column have not significantly differed each other at 5 per cent probability level.

\section{Available Nitrogen, Phosphorous and Potassium}

Laboratory analysis on dynamics of available nitrogen, phosphorous and potassium status of the soil after harvest of maize is presented in the Table 3. Irrespective of maize hybrids, available nitrogen status of the soil increased over the years. It could be due to simulated effects of varied plant population and elevated fertility levels. Among the maize hybrids cultivated, plots which received maize hybrid Arjun recorded significantly higher nitrogen (268.3 $\mathrm{kg} / \mathrm{ha})$, phosphorus $(67.2 \mathrm{~kg} / \mathrm{ha}$ ) and potassium (462.1 kg/ha) status on pooled basis (Table 3). It could be due maize hybrids NK-
6240 and Super 900-M being a single cross maize hybrids having relatively longer duration made them to deplete higher amount nutrient from soil whereas Arjun being the three way cross hybrid produced lower amount of dry matter it could be the probable cause for higher residual status in the plots of hybrid Arjun. Variation in dry matter production by maize hybrids (Table 3) created clear gradients in available nutrient status of the soil which is in close agreement with the findings of Mohan Kumar et al. [10]. Planting density of maize had a significant influence on available nutrient status of soil after harvest of maize. Maize cultivated at 
lower plant density $\left(83,333\right.$ plants ha $\left.^{-1}\right)$ recorded significantly higher residual nitrogen (239.9 kg/ha), phosphorus $(72.9 \mathrm{~kg} /$ ha) and potassium ( $461.4 \mathrm{~kg} / \mathrm{ha}$ ) status of soil. It could be due to lower biomass production per hectare of maize and lower amount of nutrient removal under lower plant population. Significant built up of residual soil nutrients when maize was cultivated at lower plant density was earlier reported by Mohan Kumar et al. [10]. Successive increment in fertility levels increased the available nutrient status of the soil, application of $\mathrm{N}$ (300) $\mathrm{P}_{2} \mathrm{O}_{5}$ (130) $\mathrm{K}_{2} \mathrm{O}$
(130) kg per hectare recorded significantly higher soil available nitrogen, phosphorus and potassium status of soil after harvest of maize. It could be due to enhanced nutrient pool at elevated fertility level which might have contributed to higher residual nutrient status of soil by retaining part of external applied nutrients in soil. Similar opinion of elevated fertility levels increasing the available nutrient status of the soil after harvest of crop was also reported by Paramasivan et al. [11].

Table 3: Available nitrogen, phosphorous and potassium as influenced by hybrids, plant population and fertility levels of maize (Pooled data of two years).

\begin{tabular}{|c|c|c|c|c|}
\hline Treatment & Nitrogen (kg ha-1) & Phosphorus (kg ha-1) & Potassium (kg ha $\left.{ }^{-1}\right)$ & Total Dry Matter Production at Harvest (g/plant) \\
\hline \multicolumn{5}{|c|}{ Maize Hybrids (H) } \\
\hline $\mathrm{H}_{1}-\mathrm{NK}-6240$ & $212.2 \mathrm{~b}$ & $56.6 \mathrm{~b}$ & $439.6 b$ & $290.85 a$ \\
\hline $\mathrm{H}_{2}$-Super $900-\mathrm{M}$ & $217.5 b$ & $68.5 b$ & $442.5 b$ & $275.38 b$ \\
\hline $\mathrm{H}_{3}$-Arjun & $268.3 \mathrm{a}$ & $67.2 \mathrm{a}$ & $462.1 \mathrm{a}$ & $201.81 \mathrm{c}$ \\
\hline S. Em. \pm & 4.2 & 1.4 & 24.1 & 2.33 \\
\hline \multicolumn{5}{|c|}{ Plant population ha-1 $(\mathrm{P})$} \\
\hline$P_{1}-1,11,111$ & $225.5 b$ & $55.3 b$ & $434.8 b$ & $240.06 b$ \\
\hline$P_{2}-83,333$ & $239.9 \mathrm{a}$ & $72.9 \mathrm{a}$ & $461.4 \mathrm{a}$ & $271.96 a$ \\
\hline S. Em. \pm & 2.8 & 1.3 & 6 & 3.17 \\
\hline \multicolumn{5}{|c|}{ Fertilization Levels $\mathrm{kg} \mathrm{ha}^{-1}(\mathrm{~F})$} \\
\hline $\begin{array}{c}\mathrm{F}_{1}-\mathrm{N}(150) \mathrm{P}_{2} \mathrm{O}_{5}(65) \\
\mathrm{K}_{2} \mathrm{O}(65)\end{array}$ & $203.2 \mathrm{~d}$ & $46.3 e$ & $395.3 c$ & $218.96 \mathrm{~d}$ \\
\hline $\begin{array}{c}\mathrm{F}_{2}-\mathrm{N}(187) \mathrm{P}_{2} \mathrm{O}_{5}(81) \\
\mathrm{K}_{2} \mathrm{O}(81)\end{array}$ & $219.3 c$ & $52.5 d$ & $422.1 \mathrm{c}$ & $245.15 \mathrm{c}$ \\
\hline $\begin{array}{c}\mathrm{F}_{3}-\mathrm{N}(225) \mathrm{P}_{2} \mathrm{O}_{5}(97) \\
\mathrm{K}_{2} \mathrm{O}(97)\end{array}$ & $234.6 \mathrm{~b}$ & $67.3 \mathrm{c}$ & $457.2 \mathrm{~b}$ & $258.88 \mathrm{bc}$ \\
\hline $\begin{array}{c}\mathrm{F}_{4}-\mathrm{N}(262) \mathrm{P}_{2} \mathrm{O}_{5}(114) \\
\mathrm{K}_{2} \mathrm{O}(114)\end{array}$ & 247.2ab & $77.5 \mathrm{~b}$ & $472.7 \mathrm{ab}$ & $272.11 \mathrm{ab}$ \\
\hline $\begin{array}{c}\mathrm{F}_{5}-\mathrm{N}(300) \mathrm{P}_{2} \mathrm{O}_{5}(130) \\
\mathrm{K}_{2} \mathrm{O}(130)\end{array}$ & $259.0 \mathrm{a}$ & $76.9 \mathrm{a}$ & $493.1 \mathrm{a}$ & $284.97 a$ \\
\hline S. Em. \pm & 4.6 & 1.1 & 11.1 & 5.47 \\
\hline
\end{tabular}

Note: Means followed by same letter (S) with in a column have not significantly differed each other at 5 per cent probability level.

\section{Conclusion}

Soil enzymes are the most sensitive part of the soil resource base, hybrids and planting density did not influence the dehydrogenase activity of the soil, whereas, successive elevation in fertility level decreases the soil dehydrogenase activity of soil. Cultivation of inefficient maize hybrids at lower planting density with application of higher levels of fertility levels buid up the soil nutrient status substantially.

\section{Acknowledgement}

None.

\section{Conflict of Interest}

No conflict of interest.

\section{References}

1. Sampath O, Madhavi M, Rao CP (2014) Evaluation of genotypes and nitrogen levels for yield maximization in rabi maize (Zea Mays L.). Intl J Innov Res \& Develop 2 (9): 314-318.

2. Gu Y, Wag P, Kong C (2009) Urease, Invertase, Dehydrogenase and Polyphenoloxidase Activities In Paddy Soils Influenced By Allelophatic Rice variety. European Journal of Soil Biology 45(5/6): 436-441.

3. Salazar S, Sanchez L, Alvarez J, Valverde A, Galindo P, et al. (2011) Correlation Among Soil Enzyme Activities Under Different Forest System Management Practices. Ecological Engineering 37(8): 1123-1131.

4. Yuan B, Yue D (2012) Soil Microbial and Enzymatic Activities Across a Chronosequence of Chinese Pine Plantation Development on The Loess Plateau of China. Pedosphere 22(1): 1-12.

5. Moeskops B, Buchan D, Sleutel S, Herawaty L, Husen E, et al. (2010) Soil Microbial Communities and Activities Under Intensive Organic and Conventional Vegetable Farming In West Java, Indonesia. Applied Soil Ecology 45: 112-120. 
6. Zhang N, He X, Gao Y, Li Y, Wang H, et al. (2010) Pedogenic Carbonate and Soil Dehydrogenase Activity in Response to Soil Organic Matter in Artemisia ordosica Community. Pedosphere 20(2): 229-235.

7. Anonymous (2012) Package of practices for cultivation of maize. University of Agricultural Sciences, Dharwad.

8. Casida LE, Klein DA, Satoro T (1964) Soil dehydrogenase activity. Soil Science 98(6): 371-376.

9. Nath DJ, Ozah B, Baruah R, Barooah RC, Borah DK,et al. (2012) Soil enzyme and microbial biomass carbon under rice- toria sequence as

ISSN: 2574-1241

DOI: 10.26717/BJSTR.2019.23.003845

Mohan Kumar R. Biomed J Sci \& Tech Res

(C) This work is licensed under Creative

Submission Link: https://biomedres.us/submit-manuscript.php influenced by nutrient management. J. Indian Socity of Soil Science 60 (1): 20-24.

10. Mohan Kumar RSM, Hiremath, Nadagouda BT (2015) Effect of singlecross hybrids, plant population and fertility levels on productivity and economics of maize (Zea mays L.). Indian Journal of Agronomy 60 (3): 75-79.

11. Paramasivan M, Kumaresan KR, Malarvizhi P, Velayudham K (2014) Effect of different levels of NPK and Zn on yield and nutrient uptake by hybrid maize (COHM\%) in Pilamedu and Aplaviduthi series of Tamil Nadu. Madras Agriculture. Journal 98 (10-12): 334-338.

$\begin{array}{ll}\text { BIOMEDICAL } & \text { Assets of Publishing with us } \\ \text { RESEARCHES } & \text { - Global archiving of articles } \\ & \text { - Immediate, unrestricted online access } \\ \end{array}$

